\title{
Fluorochemicalsused in food packaging inhibit male sex hormone synthesis
}

Rosenmai, Anna Kjerstine; Nielsen, Frederik Knud ; Pedersen, Mikael; Hadrup, Niels; Trier, Xenia; Christensen, Jan H.; Vinggaard, Anne Marie

Publication date:

2012

Document Version

Publisher's PDF, also known as Version of record

Link back to DTU Orbit

Citation $(A P A)$ :

Rosenmai, A. K., Nielsen, F. K., Pedersen, M., Hadrup, N., Trier, X., Christensen, J. H., \& Vinggaard, A. M. (2012). Fluorochemicalsused in food packaging inhibit male sex hormone synthesis. Poster session presented at ILSI Europe 5th International Symposium on Food Packaging, Berlin, Germany.

\section{General rights}

Copyright and moral rights for the publications made accessible in the public portal are retained by the authors and/or other copyright owners and it is a condition of accessing publications that users recognise and abide by the legal requirements associated with these rights.

- Users may download and print one copy of any publication from the public portal for the purpose of private study or research.

- You may not further distribute the material or use it for any profit-making activity or commercial gain

- You may freely distribute the URL identifying the publication in the public portal 


\section{Fluorochemicals used in food packaging inhibit male sex hormone synthesis}

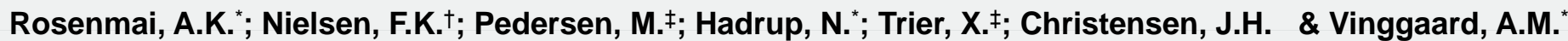

"Division of Toxicology \& Risk Assessment, National Food Institute, Technical University of Denmark, Denmark. TSection of Toxicology, Department of Pharmacy, Faculty of Health and Medical Sciences, University of Copenhagen, Denmark. ‡Division of Food Chemistry, National Food Institute, Technical University of Denmark, Denmark. Department of Basic Sciences and Environment, Faculty of Life Sciences, University of Copenhagen, Denmark.

\section{Background \& Aim}

Polyfluoroalkyl phosphate surfactants (PAPS) are widely used in food contact materials (FCMs) of paper and board and have recently been detected in $57 \%$ of investigated materials. Human exposure occurs as PAPS have been measured in blood; however knowledge is lacking on the toxicology of PAPS. Metabolic products of PAPS, fluorotelomer alcohol (FTOH) and perfluorocarboxylic acids (PFCAs) have shown potential to interfere with the endocrine system and thus the aim of this study was to elucidate the effects of six fluorochemicals on sex hormon synthesis and androgen receptor (AR) activation in vitro. Four PAPS and two metabolites, perfluorooctanoic acid (PFOA) and 8:2 fluorotelomer alcohol (8:2 FTOH) were tested.

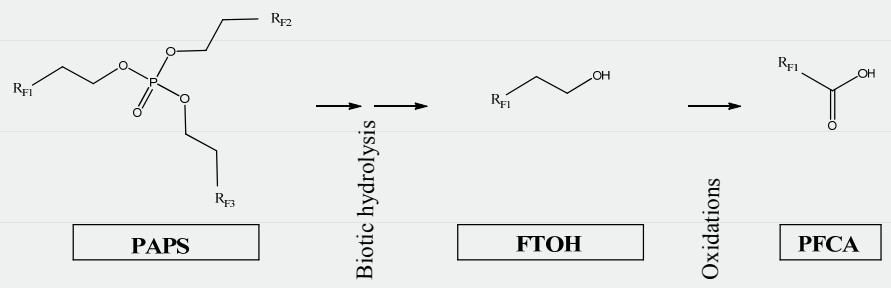

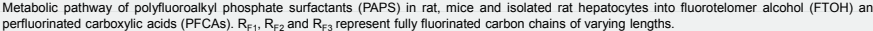

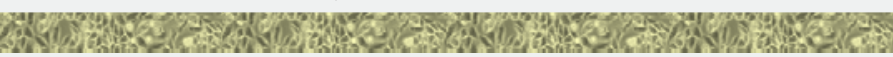

\section{Results}

Hormone profiles, including eight steroid hormones, generally showed that 8:2 diPAPS, 8:2 monoPAPS and 8:2 FTOH led to decreases in testosterone, dehydroepiandrosterone, and androstenedione in the H295R steroidogenesis assay. Decreases were observed for progesterone and 17-OH-progesterone as well. None of the compounds showed effects in the AR reporter gene assay.

\begin{tabular}{|c|c|c|c|c|c|c|c|}
\hline & & 8:2 triPAPS & 10:2 diPAPS & 8:2 diPAPS & 8:2 monoPAPS & 8:2 FTOH & PFOA \\
\hline \multirow{3}{*}{ Progesterone $^{a}$} & $\mathrm{QE}$ & $\downarrow$ & $\downarrow$ & $\downarrow$ & $\downarrow$ & $\downarrow$ & n.s. \\
\hline & $\operatorname{LOEC}(\mu \mathrm{M})$ & 12.5 & 50 & 3.1 & 50 & 3.1 & n.s. \\
\hline & $\overline{\mathrm{E}_{\max }(\%)}$ & $26 \pm 10$ & $22 \pm 16$ & $60 \pm 14$ & $42 \pm 10$ & $45 \pm 18$ & n.s. \\
\hline \multirow[t]{3}{*}{$\begin{array}{l}\text { 17-OH-Progesterone } \\
\text { b-OH- }\end{array}$} & $\mathrm{QE}$ & $\downarrow$ & $\downarrow$ & $\downarrow$ & $\downarrow$ & $\downarrow$ & n.s. \\
\hline & $\operatorname{LOEC}(\mu \mathrm{M})$ & 12.5 & 3.1 & 12.5 & 3.1 & 3.1 & n.s. \\
\hline & $\mathrm{E}_{\max }(\%)$ & $14 \pm 6$ & $28 \pm 3$ & $50 \pm 10$ & $67 \pm 3$ & $55 \pm 6$ & n.s. \\
\hline \multirow[t]{3}{*}{ Cortisol $^{b}$} & $\mathrm{QE}$ & n.s. & $\downarrow$ & $\uparrow$ & n.s. & n.s. & n.s. \\
\hline & $\overline{\operatorname{LOEC}(\mu \mathrm{M})}$ & n.s. & 3.1 & 50 & n.s & n.s. & n.s. \\
\hline & $\mathrm{E}_{\max }(\%)$ & n.s. & $25 \pm 15$ & $38 \pm 13$ & n.s. & n.s. & n.s. \\
\hline \multirow[t]{3}{*}{${\overline{\text { DHEA }^{b}}}^{\text {b }}$} & $\mathrm{QE}$ & n.s. & $\downarrow$ & $\downarrow$ & $\downarrow$ & $\downarrow$ & n.s. \\
\hline & LOEC $(u M)$ & n.s. & 3.1 & 50 & 12.5 & 12.5 & n.s. \\
\hline & $\mathrm{E}_{\max }(\%)$ & n.s. & $29 \pm 3$ & $56 \pm 8$ & $72 \pm 3$ & $39 \pm 9$ & n.s. \\
\hline \multirow[t]{3}{*}{ Androstenedione $^{b}$} & $\mathrm{QE}$ & n.s. & $\downarrow$ & $\downarrow$ & $\downarrow$ & $\downarrow$ & $\downarrow$ \\
\hline & $\overline{\operatorname{LOEC}(\mu \mathrm{M})}$ & n.s. & 12.5 & 12.5 & 12.5 & 3.1 & 12.5 \\
\hline & $\overline{E_{1}(\%)}$ & n.s. & $17 \pm 3$ & $45 \pm 6$ & $65 \pm 3$ & $54 \pm 4$ & $19 \pm 9$ \\
\hline \multirow[t]{3}{*}{ 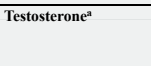 } & & $\downarrow$ & n.s. & $\downarrow$ & $\downarrow$ & $\downarrow$ & n.s. \\
\hline & $\frac{12}{\operatorname{LOEC}(\mu \mathrm{M})}$ & 50 & n.s. & 25 & $\frac{7}{25}$ & $\frac{1}{3.1}$ & n.s. \\
\hline & $\overline{\mathrm{E}_{\max }(\%)}$ & $34 \pm 21$ & n.s. & $63 \pm 10$ & $56 \pm 20$ & $53 \pm 16$ & n.s. \\
\hline \multirow{3}{*}{$\overline{\text { Estrone }^{\mathrm{b}}}$} & $\mathrm{QE}$ & $\uparrow$ & $\uparrow$ & $\uparrow$ & $\uparrow$ & $\uparrow$ & $\uparrow$ \\
\hline & $\operatorname{LOEC}(\mu \mathrm{M})$ & 12.5 & 50 & 50 & 50 & 12.5 & 12.5 \\
\hline & $\mathrm{E}_{\max }(\%)$ & $34 \pm 8$ & $30 \pm 11$ & $121 \pm 9$ & $137 \pm 82$ & $146 \pm 24$ & $75 \pm 9$ \\
\hline \multirow[t]{3}{*}{$\overline{17 \beta \text {-estradiol }{ }^{2}}$} & & n.s. & n.s. & n.s. & n.s. & & \\
\hline & $\operatorname{LOEC}(\mu \mathrm{M})$ & n.s. & n.s. & n.s. & n.s. & 12.5 & $1.6 / 50$ \\
\hline & $\overline{\mathrm{E}_{\max }(\%)}$ & n.s. & n.s. & n.s. & n.s. & $41 \pm 19$ & $24 \pm 19 / 17 \pm 22$ \\
\hline
\end{tabular}

Overview of hormone effects in the $\mathrm{H}_{295 R}$ steroidogenesis assay. The qualitative effect $(Q E)(\downarrow$ or $\quad \uparrow)$, the lowest observable effect
concentration (LOEC) and the tentative efficacy ( $E_{\max }$ ) given in \% change are shown. All values have a significance level of $p<0.05$. a)

These findings indicate that of the two tested endpoints interference with hormone synthesis is the main mechanism of effect. The characteristic hormone profiles with exposure indicated that a step prior to progestagen and androgen synthesis had been affected. Gene expression analysis of StAR, Bzrp, CYP11A, CYP17, CYP21 and CYP19 mRNA showed a decrease in Bzrp mRNA levels for 8:2 monoPAPS and 8:2 FTOH indicating interference with cholesterol transport to the inner mitochondria.

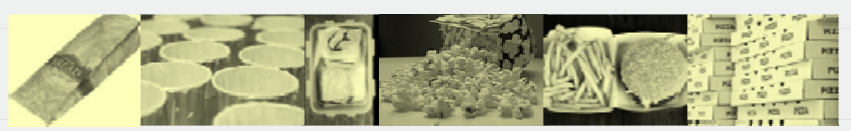

Acknowledgements

Thanks to Camilla Taxvig for assistance with handling of data, proof reading and genera support. Furthermore Heidi Letting, Dorte Lykkegaard Korsbech, Birgitte Møller Plesning, and Lis Abildgaard Andersen are thanked for technical assistance. Finally thanks to Katrine Scheibye for conducting the initial testing of PAPS.

\section{Conclusion}

Overall, the results demonstrate that of the tested endpoints interference with steroidogenesis is the main target of the test compounds. Specifically, fluorochemicals used in food packaging and their metabolites can affect steroidogenesis through decreased Bzrp and increased CYP19 gene expression causing lower androgen and higher estrogen levels.

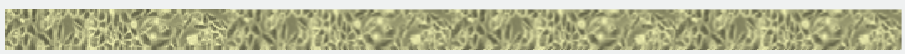
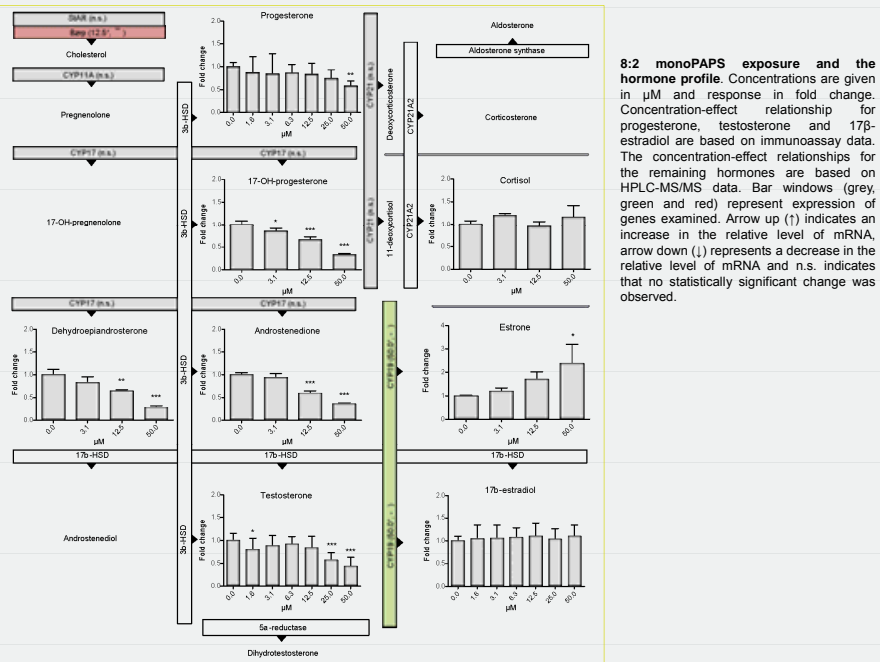

Cortisol, estrone and $17 \beta$-estradiol levels were in several cases increased with exposure. In accordance with these data CYP19 gene expression increased with 8:2 diPAPS, 8:2 monoPAPS and 8:2 FTOH exposures indicating that this is a contributing factor to the decreased androgen and the increased estrogen levels.

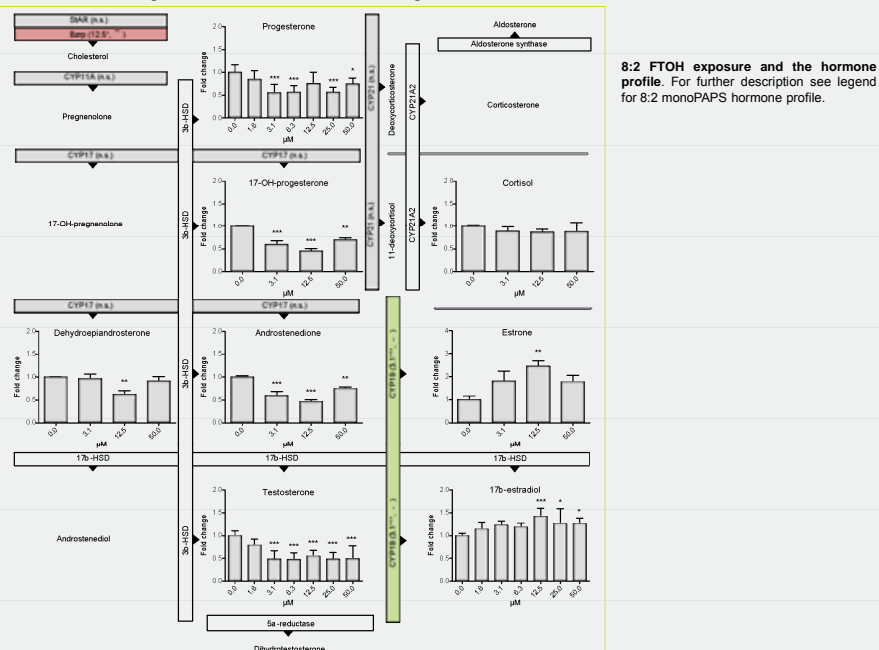

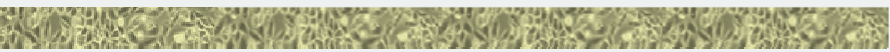
Materials and Methods

Materials and methods are described in detail in the paper Fluorochemicals used in food packaging inhibit male sex hormone synthesis (Rosenmai et al., 2012). The tested compounds include 8:2 triPAPS, 10:2 PAPS, 8:2 diPAPS and 8:2 monoPAPS and
the metabolites, 8:2 FTOH and PFOA. H295R steroidogenesis assay. The H295R cell line was cultured for 24 with the metabolites, 8:2 FTOH and PFOA. H295R steroidogenesis assay. The H295R cell line was cultured for $24 \mathrm{~h}$ with
successive test compound exposure for $48 \mathrm{~h}$. Exposure concentrations ranged from $16-50.0 \mu \mathrm{M}$. After $48 \mathrm{~h}$ exposure the supernatant was sampled for hormone analysis and cell viability was tested. Hormones were extracted from cell supernatants by
SPE and were measured both by time-resolved fluoroimmunoassays and HPLC-MS/MS. Effects on gene expression were assessed by qRT-PCR. mRNA isolation and conversion to cDNA were performed with TaqMan ${ }^{\circledR}$ Fast Cells-to-CTM Kit. cDNA was analyzed on a PCR system using TaqMan® Gene Expression Assays. Androgen receptor reporter gene assay. The assay (Erasmus University, Rotterdam). Test chemicals were added leading to final exposure concentrations ranging from $0.2-50.0$ $\mu \mathrm{M}$ on agonism, antagonism and toxicity plates. 